\title{
INTERREGIONAL REDISTRIBUTION AND BUDGET INSTITUTIONS UNDER ASYMMETRIC INFORMATION
}

\author{
BERND HUBER \\ MARCO RUNKEL
}

\author{
CESIFO WORKING PAPER NO. 1491 \\ CATEgory 1: Public Finance \\ JUNE 2005
}

An electronic version of the paper may be downloaded

- from the SSRN website: Www.SSRN.com

- from the CESifo website: www.CESifo.de 


\title{
INTERREGIONAL REDISTRIBUTION AND BUDGET INSTITUTIONS UNDER ASYMMETRIC INFORMATION
}

\begin{abstract}
Empirical evidence from the U.S. and the European Union suggests that regions which contribute to interregional redistribution face weaker borrowing constraints than regions which benefit from interregional redistribution. This paper presents an argument in favor of such differentiated budgetary institutions. It develops a two-period model of a federation consisting of two types of regions. The federal government redistributes from one type of regions (contributors) to the other type (recipients). It is shown that a fiscal constitution with lax budget rules for contributors and strict budget rules for recipients solves the self-selection problem the federal government faces in the presence of asymmetric information regarding exogenous characteristics of the regions.
\end{abstract}

JEL Code: H74, H77, D82.

Keywords: asymmetric information, interregional redistribution, borrowing rules.

Bernd Huber

Department of Economics

University of Munich

Ludwigstr. 28 / Vgb. / III

80539 Munich

Germany

huber.sekretariat@lrz.uni-muenchen.de
Marco Runkel

Department of Economics

University of Munich

Ludwigstr. 28 / Vgb. / III

80539 Munich

Germany

marco.runkel@Irz.uni-muenchen.de

We would like to thank Andreas Haufler, Nadine Riedel and Frank Westermann for helpful comments and discussions. All errors remain ours. 


\section{Introduction}

Constraints on public borrowing are widespread among U.S. states. The National Association of State Budget Office (1992) reports that all states but Vermont have statutory or constitutional balanced budget requirements or debt limits. Such budget institutions restrict the government's bond finance of current outlays. But there is a large variation in the stringency of budget rules. For instance, some states exempt special programs like capital funds, some states are allowed to issue short-term debt carrying over deficits to the next fiscal year, and some states may borrow on the behalf of a public referendum. Poterba (1996) argues that anti-deficit rules are usually more stringent in small states than in large states. Furthermore, it is well known that federal taxes and transfers in the U.S. redistribute resources from high-income to low-income states (e.g. Bayoumi and Masson, 1995, Mélitz and Zumer, 2002). Taken together these two observations we may conclude that, ceteris paribus, states which contribute to interregional redistribution face weaker borrowing constraints than states which benefit from interregional redistribution.

There is a similar budget institution in the European Union. The Stability and Growth Pact (SGP) restricts the annual deficit of member states to $3 \%$ of GDP. If a country violates this requirement, the European Commission triggers an institutional procedure which induces the country to bring down its deficit. In recent years, some countries did not satisfy the borrowing constraint. Portugal and Netherland temporarily violated the criterion in 2001 and 2003, respectively. France and Germany have run excessive deficits since 2002 and Greece has not met the 3\%-criterion since 2001. In light of this experience, the European Commission recently proposed a council regulation on clarifying the excessive deficit procedure. One important change is that in identi-

fying an excessive deficit "... special consideration will be given to budgetary efforts towards increasing or maintaining at a high level financial contributions to fostering international solidarity and to achieving European policy goals, notably the unification of Europe ..." (Commission of the European Communities, 2005). This amendment especially aims at the member countries' (net) payments to the budget of the European Union. Since one of the main purposes of this budget is to redistribute between the member states, we come to a similar conclusion as for the U.S.: Net contributors in the European Union will be subject to weaker borrowing constraints than net recipients. 
It is well known from the public finance literature, that fiscal institutions are not only 'veils' that leave unaltered the budget of a country. In a series of interesting papers, von Hagen (1991), Poterba (1994, 1995, 1996) and Poterba and Rueben (2001) empirically investigate the impact of different budgetary institutions on the spending behavior of the U.S. states. They inter alia find that public indebtedness is substantially higher in states with weak balanced budget requirements than in other states. This is exactly the reason why many researchers, politicians and central bankers are seriously concerned about relaxing the excessive deficit procedure of the SGP in the European Union. One implication will be that the member countries, especially the large countries which are also the net contributors of the European Union, may run larger deficits inducing the European Central Bank to fight inflationary pressure on the common currency by raising interest rates (e.g. Feldstein, 2005).

While this reasoning is right from a monetary point of view, the present paper argues that a fiscal constitution with strict borrowing rules for recipient countries and lax borrowing rules for contributing countries of a federation may nonetheless beneficial, if considered in the realm of fiscal federalism. Our main argument in favor of differentiated budget rules is that it can solve the self-selection problem a federal government faces in the presence of asymmetric information. We develop a two-period model of a federation consisting of a federal government (center) and two types of regions. The center redistributes from one type of regions (contributors) to the other type (recipients). Each region levies an income tax on its residents and supplies a local public good. In the first period, a region can generate additional revenue by issuing debt which has to be repaid in the second period. The types of regions differ in an exogenously given characteristic. In our basic model, we focus on different rates of time preference. But in a modified model, it is argued that the results remain completely unchanged under other sources of heterogeneity, for example, differences in the cost of regional public services or differences in labor productivity.

In this fiscal federalism model, we first characterize the welfare optimum under full information and asymmetric information. In the latter case, the exogenously given characteristic is private information of the regions and cannot be observed by the federal government. It is then shown that the federal government can implement the full information optimum by a simple redistribution scheme consisting of lump-sum taxes 
and transfers. But under asymmetric information, incentive compatibility requires that the federal government distorts the intertemporal allocation in recipient states in favor of future public consumption. It therefore cannot implement the asymmetric information optimum by the simple redistribution system. Efficiency is attained, however, if the redistribution scheme is augmented by a limit on public borrowing in recipient regions. The limit restricts current spending and effectively shifts public consumption from the present to the future. Since it applies to recipients only, budget institutions in the federation are more stringent for recipients than for contributors.

This result has normative as well as positive implications. The normative implications are important especially from an European point of view. The result shows that differentiated borrowing constraints for contributors and recipients in the European Union can be justified on efficiency grounds. This economic benefit of an institutional change in the excessive deficit procedure of the SGP has to be balanced against possible drawbacks. The positive implications are relevant especially for the U.S. states. While a lot of studies identify the impact of different budget institutions on e.g. the states' spending behavior, to the best of our knowledge no attention has been paid to the question why states face different borrowing restrictions. As we will argue in more detail, our result can be interpreted as a pork barrel policy. The federal government redistributes resources to a state, but only if the state is willing to accept and implement a stringent budget rule. This argument may help to explain the large variation in the stringency of budget institutions among U.S. states.

The driving force of our results is the assumption of asymmetric information. This assumption is based on empirical grounds. For example, in determining a Ramseytype social discount rate for six major countries, Evans and Sezer (2004) have to figure out the elasticity of marginal utility of consumption $(e)$, the long-run growth rate of per-capita consumption $(g)$ and the pure rate of time preference $(p)$. While presenting rigorous econometric estimates of $e$ and $g$, they recognize "... the difficulty of settling on a suitable measure of $p \ldots$. (p. 558) and make assumptions on the appropriate value of $p$. If it is difficult for researchers to assess the rate of time preference of major countries, it will also hardly be possible for federal governments to infer this rate in the regions of a federation. Similar evidence on asymmetric information regarding other regional characteristics can be found in previous literature which we will refer to below. 
Our analysis is related to two lines of economic literature. First, there is an extensive and interesting literature on asymmetric information in federations. This literature discusses optimal interregional redistribution under asymmetric information with respect to income or the preference for public goods (Lockwood, 1999), the cost of public goods (Lockwood, 1999, Cornes and Silva, 2002) and labor productivity (Raff and Wilson, 1997, Bordignon et al. 2001). Cremer et al. (1996) consider the case where both income and the preference for a public good are private information of the regions. The consequence of asymmetric information in a tax competition framework is analyzed in Bucovetsky et al. (1998). Cornes and Silva (2003) determine the optimal spending mix under private information and Huber and Runkel (2005) use the self-selection approach to rationalize specific types of intergovernmental grants. But all these articles use oneperiod models and, thus, do not capture the implications of asymmetric information for regional public debt and the design of budget institutions in a federation.

Second, our paper is also related to the literature on budget institutions. For example, the literature on the political economy of public debt provides arguments in favor of borrowing rules. Tabellini and Alesina (1990) and Alesina and Tabellini (1990) show that political instability leads to time-inconsistent preferences of policy makers and so gives rise to excessive and ex-ante inefficient deficits. A balanced budget rule serves as commitment device and restores efficiency. Peletier et al. (1999) extend this framework and argue that a balanced budget rule causes inefficient underinvestment of the public sector. They propose a 'Golden Rule of Government Finance' requiring the public deficit to be equal to public investment. There are many other theoretical papers on budget institutions, for example, the analysis of Schmitt-Grohé and Uribe (1997) on the role of a balanced budget rule in a neoclassical growth framework. But all these models do not discuss public debt and budgetary institutions in federations and therefore do not provide a rationale for differentiated budget rules. ${ }^{1}$

The paper is organized as follows. As a further motivation, in Section 2 we first present an econometric estimation which clarifies the evidence from the U.S.. Section 3 describes the basic theoretical model. In Section 4 and 5, we derive the welfare

\footnotetext{
${ }^{1}$ Regional debt is analyzed in the models of Goodspeed (2002) and Schultz and Sjöström (2001, 2004). But the former author focusses on bailouts in federations and the latter discuss the relation of migration and debt. They do not refer to the budget institutions considered in our paper.
} 
optimum and show how this optimum can be implemented by a suitable redistribution scheme. Section 6 briefly discusses the robustness of the results. Section 7 concludes.

\section{Empirical Evidence}

The evidence from the European Union is quite clear. If the proposed council regulation of the European Commission is implemented, and there is no doubt that it will, then the excessive debt procedure will be less restrictive for contributors than for recipients. While the $3 \%$-criterion will be strictly applied to the recipient countries, contributing countries face a borrowing limit which effectively is larger than $3 \%$ of GDP.

The evidence from the U.S. is less obvious since, strictly speaking, there is no such explicit redistribution system as in Europe. However, it is well known that federal taxes and transfers implicitly redistribute resources between the states. For example, Bayoumi and Masson (1995) and Mélitz and Zumer (2002) define a state's relative per capita personal income as that state's per capita personal income divided by the average per capita personal income of all states. They estimate the relation between the relative incomes before and after federal taxes and transfers. The results suggest that the U.S. federal government redistributes about 20 cent of every dollar difference in pre-tax incomes. Hence, redistribution from states with above average income to states with below average income is clearly an element of the U.S. tax system.

To bridge the gap to our analysis of interregional redistribution and budget institutions, we will now estimate the impact of the relative per capita income on the stringency of borrowing rules in the U.S. states. Data on per capita personal income from 1969 to 2004 are provided by the U.S. Commerce Department. With the help of these data, we compute the variable RELINC which gives a state's relative per capita personal income before federal taxes and transfers. For each state, we take the average of this variable over the whole time period 1969 to 2004. Data on the stringency of budgetary institutions are available from the Advisory Council of Intergovernmental Relations $(1987,1998)$ and Poterba and Rueben (2001). They provide an index BUDSTR ranging from 0 (lax budget rules) to 10 (stringent budget rules). The scatterplot in Figure 1 illustrates the relation between BUDSTR and RELINC.

The plot suggests that high-income states (contributors) really tend to have weaker 


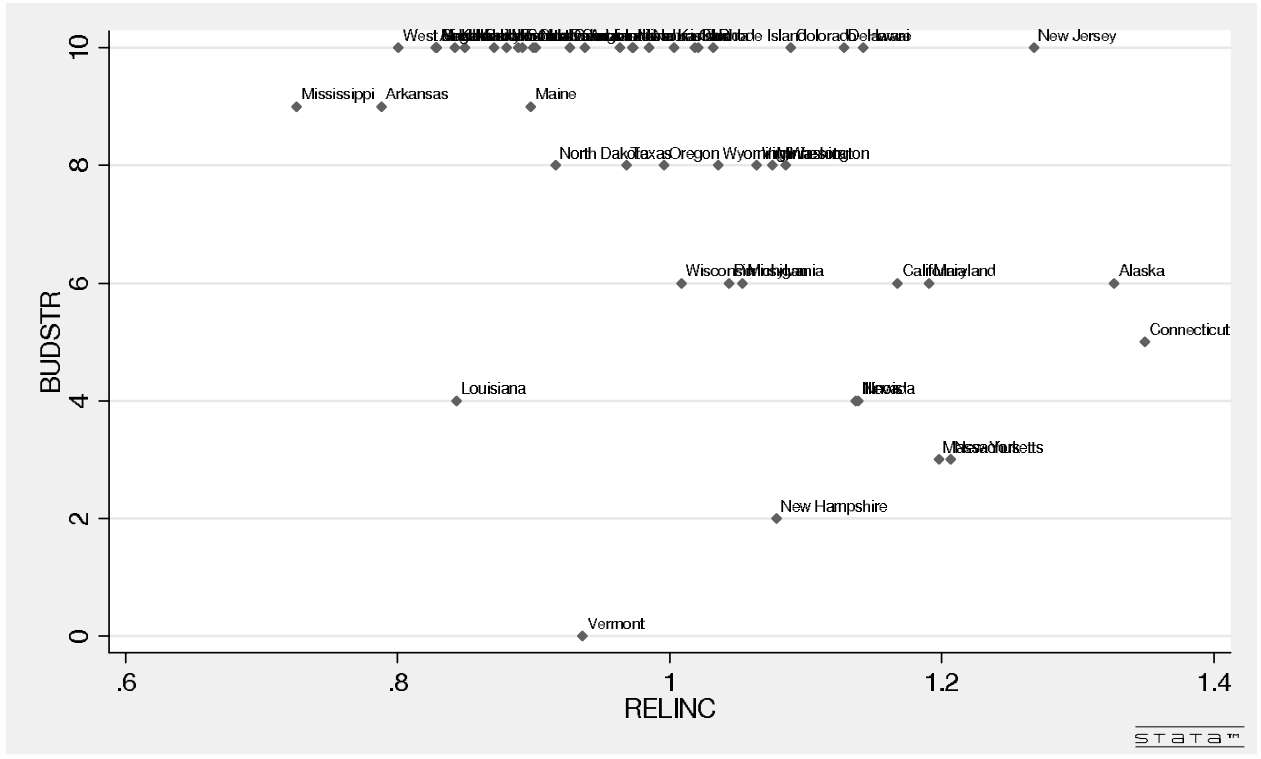

Figure 1: Budget Stringency and Relative Per Capita Income in U.S. States

borrowing rules than low-income states (recipients). This hypothesis can be tested by a simple probit regression. RELINC is taken as the independent variable. As dependent variable we construct an indicator BUDIND that receives the value 1, if BUDSTR is 9 or 10. BUDIND is set equal to zero, if BUDSTR is below 9. Since the mean of BUDSTR lies between 8 and 9, BUDIND divides the set of all states into states with above average budget stringency and states with below average budget stringency. A further motivation for BUDIND is that a state scores a 9 or 10 for BUDSTR only if it requires a strict balanced budget at the end of the fiscal year. A value of 8 for BUDSTR already indicates that the state is allowed to run a short-run deficit. If BUDIND is equal to zero (one), the borrowing constraint is said to be weak (strict). ${ }^{2}$

The results of our probit regression are displayed in Table 1 . The coefficient of RELINC is of the expected sign and statistically significant at the one percent level. To assess the economic significance, we define the average recipient (contributor) as the state with average per capita income among all states with RELINC $<1$ (RELINC $>1$ ). It is then straightforward to compute the predicted probability of the average recipient having a strict budget rule as $81.20 \%$. In contrast, the average contributor

\footnotetext{
${ }^{2}$ Poterba and Rueben (2001) use a similar indicator variable, but draw the line of demarcation between weak and strict budget institutions at BUDSTR $=6$. Under this indicator variable our empirical results slightly change, but the main conclusion remains the same.
} 
Table 1: Impact of Relative Income on Budget Stringency in U.S. States Dependent variable: BUDIND

\begin{tabular}{lrrrrc}
\hline & coeff. & std.err. & z-statistic & p-value & $95 \%$ conf. interval \\
\hline constant & 6.035 & 1.674 & 3.60 & 0.000 & {$[2.753 ; 9.316]$} \\
RELINC & -5.786 & 1.645 & -3.52 & 0.000 & {$[-9.010 ;-2.563]$} \\
\hline
\end{tabular}

Notes: (i) observations: 50, (ii) log likelihood $=-26.306$, (iii) pseudo $\mathrm{R}^{2}=0.227$.

faces a strict borrowing constraint with a probability of $32.97 \%$ only. Hence, also in the U.S. there is a clear evidence that borrowing restrictions tend to be weaker in states which contribute to interregional redistribution than in other states.

\section{Theoretical Model}

We consider a two-period model of a federation consisting of a federal government and several regions. There are two types of regions indexed by $s$ and $h$. The number of type $s$ and type $h$ regions is denoted by $m_{s} \geq 1$ and $m_{h} \geq 1$, respectively. The difference between the types of regions will be explained below. For the time being, we note that each region is populated by a cohort of $n$ identical individuals which live for one period only. After the period 1 cohort has passed away, in period 2 there is a new cohort of exactly the same size. In period $t=1,2$, an individual in a region of type $i=s, h$ consumes $c_{t i}$ units of a private good, $g_{t i}$ units of a local public good supplied by the regional government and $x_{t i}=1-\ell_{t i}$ units of leisure. $\ell_{t i}$ is the individual's labor supply. Utility of the individual is given by

$$
u_{i}=c_{t i}+W\left(x_{t i}\right)+U\left(g_{t i}\right)
$$

The functions $W$ and $U$ satisfy $W_{x}>0, W_{x x}<0, U_{g}>0$ and $U_{g g}<0$, where subscripts indicate partial derivatives. Utility is assumed to be quasi-linear in order to abstract from income effects in the supply of the local public good. In period $t$, the representative individual in region $i$ maximizes utility (1) subject to the budget constraint $c_{t i}=\left(1-\tau_{t i}\right) \ell_{t i}$, where $\tau_{t i}$ is the tax rate of an income tax imposed by the local government. The first-order condition of utility maximization is

$$
1-\tau_{t i}-W_{x}\left(1-\ell_{t i}\right)=0
$$


It determines the individual's optimal labor supply as a function of the local tax rate, i.e. $\ell_{t i}=L\left(\tau_{t i}\right)$ with $L_{\tau}\left(\tau_{t i}\right)=1 / W_{x x}<0$ and $L_{\tau \tau}\left(\tau_{t i}\right)=W_{x x x} /\left(W_{x x}\right)^{3}<0 .^{3}$

Inserting the optimal labor supply in (1) gives the indirect utility function of the representative individual in region $i$ and period $t$. The present value of region $i$ 's (per capita) welfare can then be written as

$$
\begin{aligned}
v_{i}=\left(1-\tau_{1 i}\right) L\left(\tau_{1 i}\right)+W[1- & \left.L\left(\tau_{1 i}\right)\right]+U\left(g_{1 i}\right) \\
& +\delta_{i}\left[\left(1-\tau_{2 i}\right) L\left(\tau_{2 i}\right)+W\left[1-L\left(\tau_{2 i}\right)\right]+U\left(g_{2 i}\right)\right] .
\end{aligned}
$$

$\left.\left.\delta_{i}=1 /\left(1+\rho_{i}\right) \in\right] 0,1\right]$ denotes the discount factor and $\rho_{i} \geq 0$ is the discount rate or, equivalently, the rate of time preference in region $i$. We assume $\delta_{s}<\delta_{h}$. A region of type $s$ has a smaller discount factor (a higher discount rate) than a region of type $h$. Type $s$ regions discount the future more and place lower weight on the well-being of future generations than type $h$ regions. Thus, $\delta_{i}$ can also be interpreted as an intergenerational altruism parameter of the first-period inhabitants of region $i$.

In each period, the local government of a type $i$ region finances its public good supply by the revenue of the income tax. Moreover, in period 1 it additionally receives a transfer $z_{i}$ from the central government and may issue debt $b_{i}$. The debt plus interest payments has to be paid back in period 2. We assume that all regions borrow on the world capital market and take as given the interest rate $r \geq 0$. The local government's budget constraints in period 1 and 2 can be written as, respectively,

$$
g_{1 i}=n \tau_{1 i} L\left(\tau_{1 i}\right)+b_{i}+z_{i}, \quad g_{2 i}=n \tau_{2 i} L\left(\tau_{2 i}\right)-(1+r) b_{i}
$$

The transfer from the center is not restricted in sign. If it is negative, it represents a tax that the federal government imposes on a type $i$ region. As we explain in more detail below, the sole objective of the center is to optimally redistribute between the regions. Its budget constraint reads

$$
m_{s} z_{s}+m_{h} z_{h}=0
$$

\footnotetext{
${ }^{3}$ Note that $W_{x}>0$ and $W_{x x}<0$ imply $W_{x x x}>0$, provided all derivatives of $W$ are monotone for $x \geq 0$ (Menegatti, 2001). The most frequently used utility functions have monotone derivatives, for instance, the CES function $W(x)=\left(x^{1-\alpha}-1\right) /(1-\alpha)$ with $\left.\left.\alpha \in\right] 0,1\right]$, which for $\alpha=1$ encompasses the logarithmic function $W(x)=\ln \{1+x\}$, and the exponential function $W(x)=1-\exp \{-\alpha x\}$ with $\alpha>0$. A counterexample is $W(x)=\alpha x-\beta x^{2}$ with $x<\alpha / 2 \beta$ and $\alpha, \beta>0$. This function implies $W_{x x x}=0$. But we then obtain $L_{\tau \tau}=0$ and all our subsequent results remain true.
} 
This budget constraint completes the model. It implies that the center collects resources from one type of regions to finance the transfers to the other type of regions. ${ }^{4}$

For the proofs of our results, it it is useful to determine the properties of a region's preferences in the debt-transfer space. For this, we maximize region $i$ 's welfare (3) with respect to the first- and second-period income tax rates and, for the time being, take as given debt and the federal transfer. The result is the region's welfare function

$$
\begin{aligned}
V(b, z, \delta)=\max _{\tau_{1}, \tau_{2}}\left\{\left(1-\tau_{1}\right) L\left(\tau_{1}\right)+W\left[1-L\left(\tau_{1}\right)\right]+U\left[n \tau_{1} L\left(\tau_{1}\right)+b+z\right]\right. \\
\left.+\delta\left[\left(1-\tau_{2}\right) L\left(\tau_{2}\right)+W\left[1-L\left(\tau_{2}\right)\right]+U\left[n \tau_{2} L\left(\tau_{2}\right)-(1+r) b\right]\right]\right\}
\end{aligned}
$$

where, for notational convenience, the region index $i$ is suppressed. The first-order conditions of the maximization problem in (6) can be written as

$$
n U_{g}\left(g_{1}\right)=1-\frac{\tau_{1} L_{\tau}\left(\tau_{1}\right)}{L\left(\tau_{1}\right)+\tau_{1} L_{\tau}\left(\tau_{1}\right)}, \quad n U_{g}\left(g_{2}\right)=1-\frac{\tau_{2} L_{\tau}\left(\tau_{2}\right)}{L\left(\tau_{2}\right)+\tau_{2} L_{\tau}\left(\tau_{2}\right)},
$$

with $g_{1}=n \tau_{1} L\left(\tau_{1}\right)+b+z$ and $g_{2}=n \tau_{2} L\left(\tau_{2}\right)-(1+r) b$. Equation $(7)$ represents the well-known modified Samuelson rule for the provision of public goods in the presence of distortionary income taxation (e.g. Atkinson and Stiglitz, 1980). In each period, the sum of the marginal willingness to pay for the public good is equated to the marginal cost of the public good and the tax distortion cost. Hence, in our model the intratemporal supply of the public good is distorted by the income tax only, independent of the information structure. Equation (7) also implies $L\left(\tau_{t}\right)+\tau_{t} L_{\tau}\left(\tau_{t}\right)>0$, i.e. the regions are always on the increasing side of the Laffer curve.

Equation (7) determines the region's optimal income tax rates as functions of debt and the federal transfer. Formally, we have $\tau_{1}=T^{1}(b, z)$ and $\tau_{2}=T^{2}(b)$ with

$$
\begin{gathered}
T_{b}^{1}(b, z)=T_{z}^{1}(b, z)=-\frac{n U_{g g}^{1}\left(L^{1}+\tau_{1} L_{\tau}^{1}\right)}{n^{2}\left(L^{1}+\tau_{1} L_{\tau}^{1}\right)^{2} U_{g g}^{1}+n U_{g}^{1}\left(2 L_{\tau}^{1}+\tau_{1} L_{\tau \tau}^{1}\right)-L_{\tau}^{1}}<0 \\
T_{b}^{2}(b)=\frac{n(1+r) U_{g g}^{2}\left(L^{2}+\tau_{2} L_{\tau}^{2}\right)}{n^{2}\left(L^{2}+\tau_{2} L_{\tau}^{2}\right)^{2} U_{g g}^{2}+n U_{g}^{2}\left(2 L_{\tau}^{2}+\tau_{2} L_{\tau \tau}^{2}\right)-L_{\tau}^{2}}>0
\end{gathered}
$$

\footnotetext{
${ }^{4}$ Attention is restricted to redistribution in period 1 since we are interested in the relation between redistribution and public borrowing, the latter taking place also in the first period only. But it is straightforward to show that our main results are not affected, if the federal government is supposed to redistribute in the second period or in both periods.
} 
where $L^{t}:=L\left(\tau_{t}\right), L_{\tau}^{t}:=L_{\tau}\left(\tau_{t}\right), U_{g}^{t}:=U_{g}\left(g_{t}\right)$ and so on. The denominators of (8) and (9) are negative due to the second-order conditions of the maximization problem (6). Equation (8) states that an increase in public borrowing or in the federal transfer allows to reduce the income tax rate in period 1. According to (9), higher debt requires a larger tax rate in period 2 since debt has to be repaid in the second period.

Applying the envelope theorem to the region's welfare function (6), we obtain the slope of an indifference curve in the $(b, z)$-space

$$
\left.\frac{d z}{d b}\right|_{d V=0}=-\frac{U_{g}\left[n \tau_{1} L\left(\tau_{1}\right)+b+z\right]-\delta(1+r) U_{g}\left[n \tau_{2} L\left(\tau_{2}\right)-(1+r) b\right]}{U_{g}\left[n \tau_{1} L\left(\tau_{1}\right)+b+z\right]},
$$

with $\tau_{1}=T^{1}(b, z)$ and $\tau_{2}=T^{2}(b)$. The curvature can be written as

$$
\begin{gathered}
\left.\frac{d^{2} z}{d b^{2}}\right|_{d V=0}=\frac{\delta^{2}(1+r)^{2}\left[L^{1} L_{\tau}^{1}+\tau_{1} L^{1} L_{\tau \tau}^{1}-\tau_{1}\left(L_{\tau}^{1}\right)^{2}\right] U_{g}^{2} T_{b}^{1}}{n\left(L^{1}+\tau_{1} L_{\tau}^{1}\right)^{2}\left(U_{g}^{1}\right)^{3}} \\
-\frac{\delta(1+r)\left[L^{2} L_{\tau}^{2}+\tau_{2} L^{2} L_{\tau \tau}^{2}-\tau_{2}\left(L_{\tau}^{2}\right)^{2}\right] T_{b}^{2}}{n\left(L^{2}+\tau_{2} L_{\tau}^{2}\right)^{2} U_{g}^{1}}>0 .
\end{gathered}
$$

Hence, the indifference curve is U-shaped with the minimum at the point where the intertemporal rate of substitution equals the intertemporal rate of transformation, i.e. $U_{g}\left(g_{1}\right) / \delta U_{g}\left(g_{2}\right)=1+r$. To understand the difference between a $s$-region indifference curve and a $h$-region indifference curve, differentiate (10) with respect to the discount factor. The result is

$$
\frac{d}{d \delta}\left(\left.\frac{d z}{d b}\right|_{d V=0}\right)=\frac{(1+r) U_{g}^{2}}{U_{g}^{1}}>0
$$

$\delta_{h}>\delta_{s}$ implies that, in every point in the $(b, z)$-space, the indifference curve of a $h$-region has larger slope than the indifference curve of a $s$-region. This property represents the single-crossing property in our model. Two given indifference curves of $h$-regions and $s$-regions cross only once.

\section{Welfare Optimum}

In this section, we analyze the welfare maximizing policy of the federal government. In doing so, we consider two different information structures. As a benchmark, attention is paid to the case in which the federal government is able to observe all variables and characteristics of the regions. The associated welfare optimum is called full information 
optimum. In the second case, the rate of time preference is private information of the regions. The federal government cannot infer whether a region places low or high weight on the welfare of future generations. This asymmetric information assumption can be motivated by the empirical evidence referred to in the introduction. The resulting welfare optimum is the asymmetric information optimum.

The objective of the center is to maximize total welfare subject to its budget constraint. Under asymmetric information, it additionally takes into account incentive compatibility constraints which ensure that each region has a (weak) incentive to truthfully reveal its type. ${ }^{5}$ According to the revelation principle, the federal government offers each type of regions a contract stipulating the federal transfer and the region's debt. Formally, the welfare maximization problem reads

$$
\max _{b_{s}, z_{s}, b_{h}, z_{h}} m_{s} V\left(b_{s}, z_{s}, \delta_{s}\right)+m_{h} V\left(b_{h}, z_{h}, \delta_{h}\right)
$$

subject to (5) and

$$
\begin{aligned}
& V\left(b_{s}, z_{s}, \delta_{s}\right) \geq V\left(b_{h}, z_{h}, \delta_{s}\right), \\
& V\left(b_{h}, z_{h}, \delta_{h}\right) \geq V\left(b_{s}, z_{s}, \delta_{h}\right) .
\end{aligned}
$$

$\left(\mathrm{IC}_{s}\right)$ and $\left(\mathrm{IC}_{h}\right)$ are the incentive constraints for $s$ - and $h$-regions, respectively. ( $\mathrm{IC}_{s}$ ) requires that a $s$-region must not obtain lower utility from its own contract than from the contract offered to $h$-regions. An analogous interpretation applies to $\left(\mathrm{IC}_{h}\right)$.

Note that the use of the Utilitarian welfare function (13) may raise conceptual issues. This function simply sums the welfare of all regions and places equal weight to both types of regions. Maximizing the function therefore yields one special point on the Pareto utility frontier of the federation. The use of the Utilitarian welfare function is nonetheless justified. It reveals the basic mechanism behind the general model. Moreover, in Section 6 we will argue that our main results remain unchanged, if the federal government places different weights to $s$ - and $h$-regions and if the weight assigned to $s$-regions is not higher than a certain threshold value.

Using the envelope theorem, the first-order conditions to (13) can be written as

$$
\left(m_{s}+\mu_{s}\right)\left[U_{g}\left(g_{1 s}\right)-\delta_{s}(1+r) U_{g}\left(g_{2 s}\right)\right]-\mu_{h}\left[U_{g}\left(g_{1 s}\right)-\delta_{h}(1+r) U_{g}\left(g_{2 s}\right)\right]=0,
$$

\footnotetext{
${ }^{5}$ As usual in the fiscal federalism literature, participation constraints are ignored. The underlying assumption is that leaving the federation is prohibitively costly for a region.
} 


$$
\begin{gathered}
\left(m_{h}+\mu_{h}\right)\left[U_{g}\left(g_{1 h}\right)-\delta_{h}(1+r) U_{g}\left(g_{2 h}\right)\right]-\mu_{s}\left[U_{g}\left(g_{1 h}\right)-\delta_{s}(1+r) U_{g}\left(g_{2 h}\right)\right]=0, \\
\left(m_{s}+\mu_{s}-\mu_{h}\right) U_{g}\left(g_{1 s}\right)-\lambda m_{s}=0, \\
\left(m_{h}+\mu_{h}-\mu_{s}\right) U_{g}\left(g_{1 h}\right)-\lambda m_{h}=0 .
\end{gathered}
$$

$\lambda, \mu_{s}$ and $\mu_{h}$ are the Lagrange multipliers associated with $(5),\left(\mathrm{IC}_{s}\right)$ and $\left(\mathrm{IC}_{h}\right)$, respectively. In addition to (14) to (17), we have to take into account the slackness conditions associated with the incentive constraints $\left(\mathrm{IC}_{s}\right)$ and $\left(\mathrm{IC}_{h}\right)$. Throughout we suppose the federal budget constraint is binding so that $\lambda>0$.

As a benchmark, consider first the welfare optimum in case of full information. The center can directly observe the type of a region and ignores the incentive constraints. In (14) to (17) we have to set $\mu_{s} \equiv \mu_{h} \equiv 0$. Denoting optimal values under full information by the superscript 'o', we obtain

Proposition 1. The full information optimum satisfies

$$
\frac{U_{g}\left(g_{1 i}^{o}\right)}{\delta_{i} U_{g}\left(g_{2 i}^{o}\right)}=1+r, \quad i \in\{s, h\}
$$

and $g_{1 s}^{o}=g_{1 h}^{o}, \tau_{1 s}^{o}=\tau_{1 h}^{o}, g_{2 s}^{o}<g_{2 h}^{o}, \tau_{2 s}^{o}>\tau_{2 h}^{o}, b_{s}^{o}>b_{h}^{o}$ and $z_{s}^{o}<0<z_{h}^{o}$. Moreover, it satisfies $\left(I C_{h}\right)$, but violates $\left(I C_{s}\right)$.

Proof: $U_{g}\left(g_{1 i}^{o}\right) / \delta_{i} U_{g}\left(g_{2 i}^{o}\right)=1+r, i \in\{s, h\}$, follows from (14), (15) and $\mu_{s} \equiv \mu_{h} \equiv 0$. Inserting $\mu_{s} \equiv \mu_{h} \equiv 0$ in (16) and (17) yields $U_{g}\left(g_{1 s}^{o}\right)=U_{g}\left(g_{1 h}^{o}\right)$ and $g_{1 s}^{o}=g_{1 h}^{o}$. Since (7) holds in both types of regions, we obtain $\tau_{1 s}^{o}=\tau_{1 h}^{o}$. Using (16) and (17) in (14) and (15) yields $\delta_{s} U_{g}\left(g_{2 s}^{o}\right)=\delta_{h} U_{g}\left(g_{2 h}^{o}\right)$. It follows $U_{g}\left(g_{2 s}^{o}\right)>U_{g}\left(g_{2 h}^{o}\right)$ and $g_{2 s}^{o}<g_{2 h}^{o} . \tau_{2 s}^{o}>\tau_{2 h}^{o}$ is then implied by $(7)$ because $F(\tau):=1-\tau L_{\tau}(\tau) /\left[L(\tau)+\tau L_{\tau}(\tau)\right]$ is an increasing function according to $F_{\tau}(\tau)=\left[\tau\left(L_{\tau}\right)^{2}-L L_{\tau}-\tau L L_{\tau \tau}\right] /\left(L+\tau L_{\tau}\right)^{2}>0 . g_{2 s}^{o}<g_{2 h}^{o}$ yields $(1+r)\left(b_{s}^{o}-b_{h}^{o}\right)>n\left[\tau_{2 s}^{o} L\left(\tau_{2 s}^{o}\right)-\tau_{2 h}^{o} L\left(\tau_{2 h}^{o}\right)\right]>0$. Remember that both types of regions are on the increasing side of the Laffer curve and $\tau_{2 s}^{o}>\tau_{2 h}^{o}$. Thus, $b_{s}^{o}>b_{h}^{o} . g_{1 s}^{o}=g_{1 h}^{o}$ and $\tau_{1 s}^{o}=\tau_{1 h}^{o}$ implies $z_{s}^{o}=z_{h}^{o}+b_{h}^{o}-b_{s}^{o}<z_{h}^{o}$. By (5) we obtain $z_{s}^{o}<0<z_{h}^{o}$. It remains to check the incentive compatibility constraints. Using the information derived so far, we can write $V\left(b_{s}^{o}, z_{s}^{o}, \delta_{s}\right)-V\left(b_{h}^{o}, z_{h}^{o}, \delta_{s}\right)=\delta_{s}\left[P\left(\tau_{2 s}^{o}\right)+U\left(g_{2 s}^{o}\right)-P\left(\tau_{2 h}^{o}\right)-U\left(g_{2 h}^{o}\right)\right]$ with $P(\tau):=(1-\tau) L(\tau)+W[1-L(\tau)]$ and $P_{\tau}(\tau)=-L(\tau)<0 . g_{2 s}^{o}<g_{2 h}^{o}$ and $\tau_{2 s}^{o}>\tau_{2 h}^{o}$ then imply $V\left(b_{s}^{o}, z_{s}^{o}, \delta_{s}\right)-V\left(b_{h}^{o}, z_{h}^{o}, \delta_{s}\right)<0$, i.e. $\left(\mathrm{IC}_{s}\right)$ is violated. By the same argument, we 
immediately obtain $V\left(b_{h}^{o}, z_{h}^{o}, \delta_{h}\right)-V\left(b_{s}^{o}, z_{s}^{o}, \delta_{h}\right)=\delta_{h}\left[P\left(\tau_{2 h}^{o}\right)+U\left(g_{2 h}^{o}\right)-P\left(\tau_{2 s}^{o}\right)-U\left(g_{2 s}^{o}\right)\right]>$ 0 so that $\left(\mathrm{IC}_{h}\right)$ is satisfied.

Proposition 1 states that, under full information, the intertemporal provision of the public good is undistorted. In both types of regions, the intertemporal rate of substitution between the public good in period 1 and the public good in period 2 equals the intertemporal rate of transformation. Since all regions have the same marginal utility of first-period consumption, the quantity of the public good and the tax rate in period 1 are the same across regions. In contrast, the discounted marginal utility of second-period consumption is higher for $h$-regions than for $s$-regions. High-preference regions realize a lower tax rate and a higher quantity of the public good in period 2. To finance the higher consumption, the center redistributes from low-preference regions (contributors) to high-preference regions (recipients). Moreover, debt of s-regions is higher than that of $h$-regions. While this insight implies that contributors are allowed to issue more debt than recipients, it is important to note that it does not yet make the point for differentiated borrowing constraints. As will be shown in the next section, the full information optimum can be implemented without any budget institutions.

Let us now turn to the case of asymmetric information. Since the rate of time preference is private information, a region of a given type can mimic a region of the other type. As shown in Proposition 1, this information structure implies that the full information optimum is not incentive compatible. It satisfies the incentive constraint of $h$-regions, but violates that of $s$-regions. Low-preference regions have to finance the federal redistribution and, thus, by mimicking high-preference regions they receive a federal transfer and increase their welfare. To ensure incentive compatibility, the center has to change the optimal contracts such that both incentive constraints are satisfied. Denoting optimal values under asymmetric information by a star, we obtain

Proposition 2. The asymmetric information optimum satisfies

$$
\frac{U_{g}\left(g_{1 s}^{*}\right)}{\delta_{s} U_{g}\left(g_{2 s}^{*}\right)}=1+r, \quad \frac{U_{g}\left(g_{1 h}^{*}\right)}{\delta_{h} U_{g}\left(g_{2 h}^{*}\right)}>1+r
$$

and $g_{1 s}^{*}>g_{1 h}^{*}, \tau_{1 s}^{*}<\tau_{1 h}^{*}, g_{2 s}^{*}<g_{2 h}^{*}, \tau_{2 s}^{*}>\tau_{2 h}^{*}, b_{s}^{*}>b_{h}^{*}$ and $z_{s}^{*}<0<z_{h}^{*}$.

Proof: Suppose $\left(\mathrm{IC}_{h}\right)$ is not binding so that $\mu_{h}=0$. This will be proven below. It follows $\mu_{s}>0$ since otherwise (14) to (17) would yield the full information optimum 
which violates $\left(\mathrm{IC}_{s}\right)$ according to Proposition 1. (14) and $\mu_{h}=0$ immediately imply $U_{g}\left(g_{1 s}^{*}\right) / \delta_{s} U_{g}\left(g_{2 s}^{*}\right)=1+r$. From (15) we obtain

$$
\left(m_{h}-\mu_{s}\right) U_{g}\left(g_{1 h}^{*}\right)=\left(m_{h} \delta_{h}-\mu_{s} \delta_{s}\right)(1+r) U_{g}\left(g_{2 h}^{*}\right)>\left(m_{h}-\mu_{s}\right) \delta_{h}(1+r) U_{g}\left(g_{2 h}^{*}\right)
$$

since $\delta_{s}<\delta_{h}$. (17) and $\mu_{h}=0$ imply $m_{h}-\mu_{s}>0$. Thus, $U_{g}\left(g_{1 h}^{*}\right) / \delta_{h} U_{g}\left(g_{2 h}^{*}\right)>1+r$. Solving (16) and (17) with respect to $\lambda$ yields

$$
\frac{m_{s}+\mu_{s}}{m_{s}} U_{g}\left(g_{1 s}^{*}\right)=\frac{m_{h}-\mu_{s}}{m_{h}} U_{g}\left(g_{1 h}^{*}\right) .
$$

Moreover, we have $\left(m_{s}+\mu_{s}\right) / m_{s}>1>\left(m_{h}-\mu_{s}\right) / m_{h}$ and, thus, $U_{g}\left(g_{1 s}^{*}\right)<U_{g}\left(g_{1 h}^{*}\right)$. It follows $g_{1 s}^{*}>g_{1 h}^{*}$. From $(7)$ we obtain $F\left(\tau_{1 s}^{*}\right)=n U_{g}\left(g_{1 s}^{*}\right)<n U_{g}\left(g_{1 h}^{*}\right)=F\left(\tau_{1 h}^{*}\right)$. This implies $\tau_{1 s}^{*}<\tau_{1 h}^{*}$ since $F_{\tau}(\tau)>0$. To prove $b_{s}^{*}>b_{h}^{*}$ and $z_{s}^{*}<0<z_{h}^{*}$, note first that $\left(\mathrm{IC}_{s}\right)$ is binding due to $\mu_{s}>0$. Hence, both contracts $\left(b_{s}^{*}, z_{s}^{*}\right)$ and $\left(b_{h}^{*}, z_{h}^{*}\right)$ lie on the same indifference curve of $s$-regions. In addition, $\left(b_{s}^{*}, z_{s}^{*}\right)$ lies at the minimum of this indifference curve according to $U_{g}\left(g_{1 s}^{*}\right) / \delta_{s} U_{g}\left(g_{2 s}^{*}\right)=1+r$ and (10). The U-shape of the indifference curve then implies $z_{s}^{*}<0<z_{h}^{*}$. $\left(b_{h}^{*}, z_{h}^{*}\right)$ lies on the decreasing part of the indifference curve of $h$-regions since $U_{g}\left(g_{1 h}^{*}\right) / \delta_{h} U_{g}\left(g_{2 h}^{*}\right)>1+r$. The single-crossing property $(12)$ then proves $b_{s}^{*}>b_{h}^{*}$. Furthermore, $\left(\mathrm{IC}_{h}\right)$ is satisfied as presupposed. It remains to show $g_{2 s}^{*}<g_{2 h}^{*}$ and $\tau_{2 s}^{*}>\tau_{2 h}^{*} . b_{s}^{*}>b_{h}^{*}$ implies $g_{2 s}^{*}-g_{2 h}^{*}<n\left[\tau_{2 s}^{*} L\left(\tau_{2 s}^{*}\right)-\right.$ $\left.\tau_{2 h}^{*} L\left(\tau_{2 h}^{*}\right)\right]$. By this inequality, $g_{2 s}^{*} \geq g_{2 h}^{*}$ would imply $\tau_{2 s}^{*}>\tau_{2 h}^{*}$. Remember that both types of regions are on the increasing side of the Laffer curve. But by (7), $g_{2 s}^{*} \geq g_{2 h}^{*}$ also implies $F\left(\tau_{2 s}^{*}\right)=n U_{g}\left(g_{2 s}^{*}\right) \leq n U_{g}\left(g_{2 h}^{*}\right)=F\left(\tau_{2 h}^{*}\right)$ and $\tau_{2 s}^{*} \leq \tau_{2 h}^{*}$, a contradiction. It follows $g_{2 s}^{*}<g_{2 h}^{*}$ and by equation $(7) \tau_{2 s}^{*}>\tau_{2 h}^{*}$.

In the asymmetric information optimum characterized in Proposition 2, the intertemporal allocation in low-preference regions is still not distorted. This result reflects the no-distortion-at-the-top property in our model. Incentive compatibility is ensured by two other properties. First, low-preference regions obtain an informational rent in the sense that their public consumption is increased. Their first-period public good consumption is now larger than in $h$-regions. Note also that, in the first period, $s$ regions have the lower income tax rate and, thus, the higher pre- and after-tax labor income. Second, the intertemporal allocation in high-preference regions is distorted. The marginal rate of substitution between current and future public consumption exceeds the marginal rate of transformation. There is a tendency to underprovision in 
period 1 and overprovision in period 2, and high-preference regions are forced to lower their debt. This distortion makes it unattractive for $s$-regions to mimic $h$-regions.

Proposition 2 also shows that the information asymmetry does not change the direction of redistribution in the federation. Low-preference (high-income) regions are still the contributors and high-preference (low-income) regions the recipients. Therefore, the intertemporal allocation of contributors is undistorted while that of recipients is distorted in favor of future public consumption. This insight should be kept in mind since it is of crucial importance for the optimal design of budget institutions in the federation which we will now turn to.

\section{Implementation}

In the welfare analysis of the previous section, we implicitly assumed that the federal government can directly control the allocation in the federation, i.e. can directly choose the level of spending, taxation and borrowing in the regions. Such a setting can serve as a normative benchmark, but it is obviously not consistent with observed policies in real world federations. Federal governments are usually responsible for interregional redistribution only and regions have considerable autonomy in the choice of regional policies. In this section, we therefore analyze which redistribution scheme allows the federal government to implement the welfare optimum, if the spending, taxation and borrowing decisions are decentralized at the regional level.

We consider two redistribution schemes of the federal government listed in Table 2. Both schemes consists of a $c$ - and a $r$-program. The $c$-program aims at contributors of

Table 2: Alternative Federal Redistribution Schemes

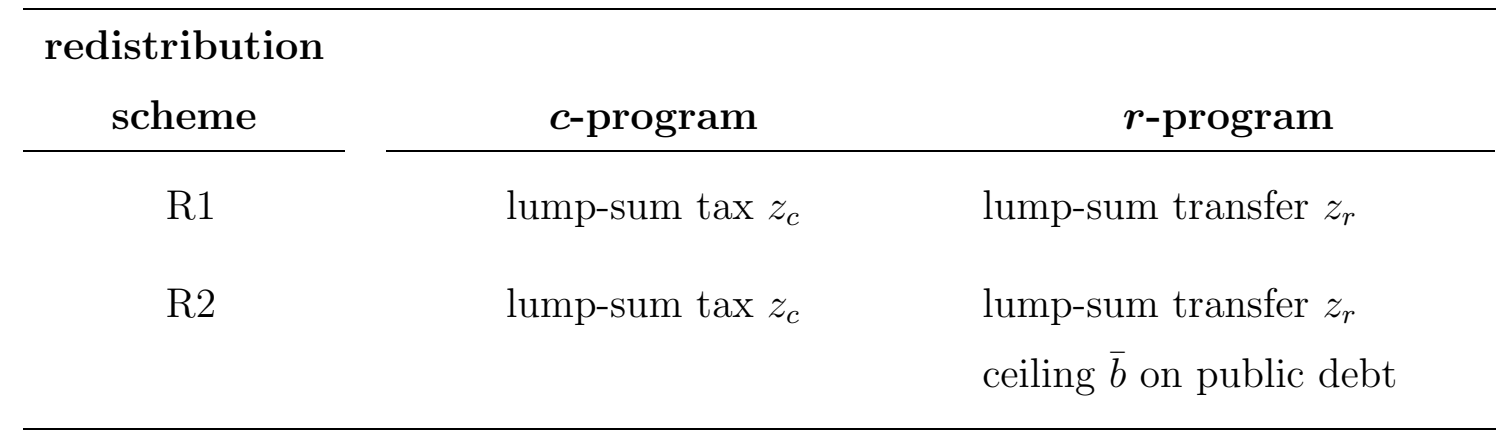


the federal redistribution, i.e. $s$-regions. It contains a lump-sum tax which contributors have to pay to the federal government. The $r$-program is designed for recipients of the federal redistribution, i.e. $h$-regions. It comprises a lump-sum transfer which the federal government pays to recipients. Under redistribution scheme R2, the transfer is combined with a ceiling $\bar{b}$ on regional debt. The recipients' debt must not exceed this limit. Note that the ceiling is applied only under the $r$-program. Regions facing the c-program may issue higher debt. Hence, scheme R2 resembles the fiscal institution which we found in the U.S. and the European Union since, roughly speaking, it implies that recipient regions face stricter borrowing restrictions than contributing regions.

The regions take as given the redistribution system of the federal government and choose public debt in order to maximize their own welfare. By this choice, the regions also implicitly determine their tax rates and quantities of the public good in both periods. Under the $c$-program, the budget constraints of a type $i$ region are represented by (4) with $z_{i}=-z_{c}$. Welfare maximization of this region can therefore be written as

$$
\max _{b_{i}} V\left(b_{i},-z_{c}, \delta_{i}\right)
$$

Under the $r$-program of redistribution scheme R1, a region of type $i$ faces the budget constraints in (4) with $z_{i}=z_{r}$. It therefore solves the same problem as in (18) except for replacing $-z_{c}$ by $z_{r}$. If the region faces the $r$-program of redistribution scheme R2, it additionally has to account for the borrowing constraint $b_{i} \leq \bar{b}$.

We again start with the case of full information. It is then straightforward to show that the federal government can attain the welfare optimum by the redistribution system R1: Suppose the center assigns the $c$-program to $s$-regions and the $r$-program to $h$-regions. The center is able to do so since it observes the type of a region. Using the envelope theorem, the first-order conditions of the regions' welfare maximization problems become

$$
\begin{gathered}
U_{g}\left[n T^{1}\left(b_{s},-z_{c}\right) L\left[T^{1}\left(b_{s},-z_{c}\right)\right]+b_{s}-z_{c}\right]=\delta_{s}(1+r) U_{g}\left[n T^{2}\left(b_{s}\right) L\left[T^{2}\left(b_{s}\right)\right]-(1+r) b_{s}\right], \\
U_{g}\left[n T^{1}\left(b_{h}, z_{r}\right) L\left[T^{1}\left(b_{h}, z_{r}\right)\right]+b_{h}+z_{r}\right]=\delta_{h}(1+r) U_{g}\left[n T^{2}\left(b_{h}\right) L\left[T^{2}\left(b_{h}\right)\right]-(1+r) b_{h}\right] .
\end{gathered}
$$

If the federal government sets $z_{c}=-z_{s}^{o}$ and $z_{r}=z_{h}^{o}$, the above conditions match those of the full information welfare optimum listed in Proposition 1. It follows that the regions choose $b_{s}=b_{s}^{o}$ and $b_{h}=b_{h}^{o}$. This finding is summarized in 
Proposition 3. Consider the case of full information and redistribution scheme R1. Set $z_{c}=-z_{s}^{o}$ and $z_{r}=z_{h}^{o}$. Then the full information optimum is attained.

The intertemporal allocation in the full information optimum is not distorted. Hence, as shown in Proposition 3, the federal government can implement this optimum by scheme R1 which contains non-distortionary instruments only. The center simply has to set the federal taxes and transfers equal to their full information levels. The regions then choose the optimal debt levels. Budget institutions are not needed to implement the optimum. Therefore, a federal system with lax borrowing rules for contributors and strict borrowing rules for recipients cannot be rationalized in case of full information.

Next turn to the implementation under asymmetric information. Under this information structure, we know from Proposition 1 and 2 that the full information optimum is no longer feasible. The objective of the federal redistribution policy is then to implement the asymmetric information optimum. Since the federal government cannot observe the type of a region, a low-preference region may mimic a high-preference region in order to obtain the $r$-program instead of the $c$-program. The federal government has to shape its redistribution system such that incentive compatibility is guaranteed for both types of regions. We obtain

Proposition 4. Consider the case of asymmetric information. Then the asymmetric information optimum cannot be attained with redistribution scheme $R 1$. Under redistribution scheme R2, set $z_{c}=-z_{s}^{*}, z_{r}=z_{h}^{*}$ and $\bar{b}=b_{h}^{*}$. Then the asymmetric information optimum is attained.

Proof: Under scheme R1, the first-order conditions of the regions' welfare maximization problems are $U_{g}\left(g_{1 i}\right)=\delta_{i}(1+r) U_{g}\left(g_{2 i}\right), i=s, h$. This contradicts Proposition 2 . To prove the result for redistribution system $\mathrm{R} 2$, note first that a $s$-region facing the $c$-program realizes $\left(b_{s}^{*}, z_{s}^{*}\right)$. Under the $r$-program, the $s$-region maximizes $V\left(b_{s}, z_{h}^{*}, \delta_{s}\right)$ subject to $b_{s} \leq \bar{b}=b_{h}^{*}$. Using the envelope theorem, the derivatives of the region's welfare function can be written as

$$
\begin{aligned}
V_{b}\left(b_{s}, z_{h}^{*}, \delta_{s}\right)=U_{g}\left[n T^{1}\left(b_{s}, z_{h}^{*}\right) L\left[T^{1}\left(b_{s}, z_{h}^{*}\right)\right]+b_{s}+z_{h}^{*}\right] \\
\quad-\delta_{s}(1+r) U_{g}\left[n T^{2}\left(b_{s}\right) L\left[T^{2}\left(b_{s}\right)\right]-(1+r) b_{s}\right]
\end{aligned}
$$




$$
\begin{aligned}
V_{b b}\left(b_{s}, z_{h}^{*}, \delta_{s}\right)=[1+ & \left.n T_{b}^{1}\left(L^{1}+\tau_{1 s} L_{\tau}^{1}\right)\right] U_{g g}^{1} \\
& \quad-\delta_{s}(1+r)\left[-(1+r)+n T_{b}^{2}\left(L^{2}+\tau_{2 s} L_{\tau}^{2}\right)\right] U_{g g}^{2}
\end{aligned}
$$

(8) and (9) imply $1+n T_{b}^{1}\left(L^{1}+\tau_{1 s} L_{\tau}^{1}\right)>0$ and $-(1+r)+n T_{b}^{2}\left(L^{2}+\tau_{2 s} L_{\tau}^{2}\right)<0$. Hence, $V_{b b}(\cdot)<0$. Evaluating $(19)$ at $b_{s}=b_{h}^{*}$ yields

$$
V_{b}\left(b_{h}^{*}, z_{h}^{*}, \delta_{s}\right)=U_{g}\left(g_{1 h}^{*}\right)-\delta_{s}(1+r) U_{g}\left(g_{2 h}^{*}\right)>U_{g}\left(g_{1 h}^{*}\right)-\delta_{h}(1+r) U_{g}\left(g_{2 h}^{*}\right)>0 .
$$

The last inequality in (21) follows from Proposition 2. (21) together with $V_{b b}(\cdot)<0$ implies $V_{b}\left(b_{s}, z_{h}^{*}, \delta_{s}\right)>0$ for all $b_{s} \leq b_{h}^{*}$. Hence, under the $r$-program the $s$-region chooses $b_{s}=b_{h}^{*}$ and realizes $\left(b_{h}^{*}, z_{h}^{*}\right)$. But we know from Proposition 2 that it is indifferent between $\left(b_{s}^{*}, z_{s}^{*}\right)$ and $\left(b_{h}^{*}, z_{h}^{*}\right)$. It therefore has no incentive to mimic a $h$ region, and redistribution system $\mathrm{R} 2$ is incentive compatible for $s$-regions.

Now turn to a $h$-region and suppose first it faces the $r$-program. It then maximizes $V\left(b_{h}, z_{h}^{*}, \delta_{h}\right)$ subject to $b_{h} \leq \bar{b}=b_{h}^{*}$. The derivatives of $V$ are analogous to (19) and (20). Evaluating the first derivative at $b_{h}=b_{h}^{*}$ yields

$$
V_{b}\left(b_{h}^{*}, z_{h}^{*}, \delta_{h}\right)=U_{g}\left(g_{1 h}^{*}\right)-\delta_{h}(1+r) U_{g}\left(g_{2 h}^{*}\right)>0 .
$$

We obtain $V_{b}\left(b_{h}, z_{h}^{*}, \delta_{h}\right)>0$ for all $b_{h} \leq b_{h}^{*}$. This means that the $h$-region sets $b_{h}=b_{h}^{*}$ and realizes $\left(b_{h}^{*}, z_{h}^{*}\right)$. It has no incentive to mimic a $s$-region since $V_{b}\left(b_{h}, z_{h}^{*}, \delta_{h}\right)>$ $V_{b}\left(b_{h}, z_{s}^{*}, \delta_{h}\right)$ for all feasible $b_{h}$. Redistribution system R2 is therefore incentive compatible for $h$-regions, too.

Redistribution scheme R1 leaves undistorted the intertemporal spending decisions of all regions. But the asymmetric information optimum is characterized by a distortion of the spending decisions of high-preference regions. This is the reason why the federal government cannot use scheme R1 to attain maximum welfare under asymmetric information. In contrast, the limit on regional debt under redistribution policy R2 restricts debt of recipient regions and so distorts their spending decisions in favor of future public consumption. The debt ceiling also makes the $r$-program unattractive for contributors. They voluntarily pay the lump-sum tax under the $c$-program instead of mimicking $h$-regions. By these two properties, the redistribution system R2 implements the welfare optimum under asymmetric information.

This insight may help to justify the differentiated budgetary institutions we observe in many real world federations. The ceiling on regional debt in our model applies to 
recipient regions only. Contributing regions are not restricted in choosing their debt level and therefore face less stringent budgetary institutions than recipients. Since contributing regions are the high-income regions in the asymmetric information optimum, the theoretical result also matches our empirical finding that budget institutions are less stringent in regions with above average personal income. The main argument our theoretical analysis provides for differentiated budget rules is that they help to solve the self-selection problem of the federal government in the presence of asymmetric information. With relatively lax borrowing rules for contributors and with suitable federal transfers, each region has an incentive to truthfully reveal its type and to implement the asymmetric information welfare optimum.

With respect to the U.S. evidence, it might be seen critical that in our model the budget institutions are part of the federal redistribution system while in reality they are set by the states themselves. But this is only a matter of interpretation. Under asymmetric information, a region of a given type can mimic a region of the other type. It can effectively choose between the $c$ - and the $r$-program and, thus, it also has a choice between lax and strict borrowing rules. In this sense, the redistribution system R2 can be interpreted as pork barrel policy between the federal and the regional governments. The center redistributes resources into a region, but only if the region chooses budgetary institutions which prevent excessive public debt. Otherwise, the region is forced to pay the transfer from which the federal government finances the interregional redistribution.

\section{Extensions and Modifications}

In this section, we will briefly discuss the robustness of our results by extending or modifying the basic model. Since the formal proofs of the results are quite similar to the proofs of Proposition 1 to 4, we only report on the results and explain their intuition. Detailed proofs can be obtained upon request.

As a first extension, suppose the federal government maximizes the weighted Utilitarian welfare function $\gamma m_{s} V\left(b_{s}, z_{s}, \delta_{s}\right)+(1-\gamma) m_{h} V\left(b_{h}, z_{h}, \delta_{h}\right)$ with $\left.\gamma \in\right] 0,1[$. The wel-

fare of low-preference regions is weighted by $\gamma$, whereas the welfare of high-preference regions enters the social welfare function with the weight $1-\gamma$. This welfare function 
is more general than (13) since by varying the parameter $\gamma$ we can attain every point on the Pareto utility frontier of the federation. With $\gamma=0.5$, both types of regions receive the same welfare weights and we obtain exactly the same results as under the social welfare function (13). But in the general case, there exists a $\bar{\gamma} \in] 0.5, \delta_{h} /\left(\delta_{s}+\delta_{h}\right)[$ such that three cases have to be distinguished: case 1 with $\gamma \in] 0, \bar{\gamma}[$, case 2 with $\gamma \in\left[\bar{\gamma}, \delta_{h} /\left(\delta_{s}+\delta_{h}\right)\left[\right.\right.$ and case 3 with $\gamma \in\left[\delta_{h} /\left(\delta_{s}+\delta_{h}\right), 1[\right.$.

In case 1 , the full information optimum can be shown to satisfy $g_{2 s}^{o}<g_{2 h}^{o}$ and $\tau_{2 s}^{o}>\tau_{2 h}^{o}$ since the 'weighted' discount factor in $h$-regions, $(1-\gamma) \delta_{h}$, is larger than the one in $s$-regions, $\gamma \delta_{s}$. For $\left.\left.\gamma \in\right] 0,0.5\right]$ we additionally have $g_{1 s}^{o} \leq g_{1 h}^{o}$ and $\tau_{1 s}^{o} \geq \tau_{1 h}^{o}$ since the welfare weight of $s$-regions is not larger than that of $h$-regions. In this subcase, $\left(\mathrm{IC}_{h}\right)$ obviously is satisfied while $\left(\mathrm{IC}_{s}\right)$ is not. Though $\left.\gamma \in\right] 0.5, \bar{\gamma}[$ implies $g_{1 s}^{o}>g_{1 h}^{o}$ and $\tau_{1 s}^{o}<\tau_{1 h}^{o}$, the incentives properties of the full information optimum are the same as in the subcase $\gamma \in] 0,0.5]$. The welfare weight $\gamma$ is still sufficiently low so that mimicking is profitable for a $s$-region since the welfare gain in period 2 outweighs the welfare loss in period 1 . Hence, in case 1 the full information optimum is always incentive compatible for high-preference regions, but not for low-preference regions. This property ensures that the results derived in the previous sections remain true. The asymmetric information optimum distorts the intertemporal allocation in $h$ regions and the center can implement this optimum by redistribution scheme R2. Thus, the optimality of a redistribution system with laxer budget institutions for contributors than for recipients can be generalized to a wide class of social welfare function.

Unfortunately, a further generalization to the cases 2 and 3 is not possible. Since the welfare weight of $s$-regions is relatively high in these cases, the incentive properties of the full information optimum change. In case 2, the full information optimum satisfies the incentive constraints of both types of regions. The asymmetric information optimum is identical to the full information optimum and the federal government can implement the optimum without borrowing constraints. In case 3, the welfare weight of $s$-regions is so high that the full information optimum satisfies $\left(\mathrm{IC}_{s}\right)$, but not $\left(\mathrm{IC}_{h}\right)$. The asymmetric information optimum distorts the spending decisions of $s$-regions which are now the recipients. But the distortion is in favor of current consumption. The center can therefore implement the asymmetric information optimum by a redistribution system which comprises a floor on the recipients' debt. This result 
would contrast the result in case 1 since the redistribution system now allows for relatively lax budget rules in recipient regions, not in contributing regions. But floors on public debt are rarely observed and hardly imaginable from an empirical point of view.

For the second modification of our basic model, we return to the welfare function (13), but consider another source of information asymmetry. In the previous fiscal federalism literature, it is often argued that the federal government cannot observe the labor productivity in a region. For instance, Bordignon et al. (2001) suppose the representative individuals of the regions differ in their effective time endowment and the center cannot infer this productivity parameter. Analogously, in our model we may assume that the time endowment is the same for the first-period individuals, but not for the second-period individuals. The time constraints in period 1 and 2 then read $\ell_{1 i}+x_{1 i}=1$ and $\ell_{2 i}+x_{2 i}=1+e_{i}$ with $0<e_{s}<e_{h}$, i.e. $s$-regions have low and $h$-regions high labor productivity. Focusing on differences in period 2 is clearly simplifying. However, it allows to model in a stylized way the fact that information asymmetries with respect to future regional characteristics are usually more severe than information asymmetries with respect to current characteristics. ${ }^{6}$

In a model with differences in the labor productivity, we obtain qualitatively the same results as in the basic model with different rates of time preference. Under full information, optimal redistribution is from high-productivity to low-productivity regions. The welfare optimum is incentive compatible for recipients, but not for contributors. Consequently, the asymmetric information optimum distorts the intertemporal allocation of low-productivity regions, and the center can implement this asymmetric information optimum by imposing a debt limit on low-productivity regions. Hence, we again obtain the result that lax budget rules for contributors and strict budget rules for recipients solve the self-selection problem of the federal government.

As a final modification, we consider a third source of information asymmetry. Previous studies referred to in the introduction argue that the cost of the regional public good supply cannot be observed by the federal government. Focusing again on the more

\footnotetext{
${ }^{6}$ Official statistics and short-run forecasts provide the federal government data which exhibit informational problems, indeed, but the reliability of these data is surely higher than that of the data obtained from long-run forecasts. Regional governments are usually better informed about, for example, the long-run demographic change or other regional developments which influence labor productivity. This information advantage of the regions is surely smaller in the short-run.
} 
serve information problem in period 2, we may suppose that regions have different unit cost of the public good in the second period. Denote unit cost of a type $i$ region by $\theta_{i}$ with $\theta_{s}<\theta_{h}$. The budget constraints of region $i$ then read $g_{1 i}=n \tau_{1 i} L\left(\tau_{1 i}\right)+b_{i}+z_{i}$ and $\theta_{i} g_{2 i}=n \tau_{2 i} L\left(\tau_{2 i}\right)-(1+r) b_{i}$. In this setting, it can be shown that the direction of redistribution in the federation is determined by the elasticity of the marginal utility of the public good, $\eta:=-g U_{g g} / U_{g}$. If the center reallocates one unit of the public good in period 2 from $h$ - to $s$-regions, it gains the difference in marginal cost, but losses the difference in marginal utility of the public good. For $\eta<1$, the former effect dominates the latter and redistribution in the full information optimum is from $h$ - to $s$-regions. If $\eta>1$, the reverse is true, and $\eta=1$ implies that there is no redistribution at all. Independent of the direction of redistribution, however, the incentive properties of the full information optimum are almost always the same. Except for the pathological case $\eta=1$, the full information optimum can be shown to satisfy the incentive constraint of recipients and to violate that of contributors. Under asymmetric information, the intertemporal spending decisions of recipients are distorted in favor of future public consumption and the federal government implements this optimum by redistribution scheme R2. Hence, redistribution systems with relatively lax budget institutions for contributors are again efficient.

\section{Conclusion}

This paper developed a two-period model of a federation consisting of a federal government and several regions. Each region provides a public good financed by a distortionary income tax and, in the first-period, by public debt and a federal transfer. The regions differ with respect to the rate of time preference and the federal government redistributes from low-preference to high-preference regions. In the full information welfare optimum, the intertemporal allocation is undistorted in each region. This optimum can be implemented by a simple redistribution scheme consisting of lump-sum taxes and transfers. But under asymmetric information, the welfare optimum is characterized by a distortion of the intertemporal allocation in recipient regions. The center attains this welfare optimum, if it augments the redistribution scheme by a limit on the borrowing of recipients. This ensures incentive compatibility for contributors. 
Although we already showed that these results are quite robust with respect to variations in the shape of the social welfare function and the source of the information asymmetry, there are further sensible extensions of our analysis. Perhaps most interestingly, we considered the different sources of information asymmetry only separately. But the federal government often cannot observe several characteristics of the regions. So, our analysis may be extended to a two- or multidimensional screening problem where the federal government cannot infer, for example, the rate of time preference and labor productivity. The question is then under what conditions our result prevails and under what conditions it breaks down. These conditions may then provide further insights in the variation of budget rules in real world federation.

\section{References}

Advisory Council of Intergovernmental Relations (1987), Fiscal Discipline in the Federal System: National Reform and the Experience of the States, Washingthon, D.C.

Advisory Council of Intergovernmental Relations (1998), Significant Features of Fiscal Federalism, Vol. 2, 'Revenues and Expenditures', Washingthon, D.C.

Alesina, A. and G. Tabellini (1990), 'A Positive Theory of Fiscal Deficits and Government Debt', Review of Economic Studies 57, 403-414.

Atkinson, A.B. and J.E. Stiglitz (1980)), Lectures on Public Economics, London: McGraw-Hill.

Bayoumi, T., and P. Masson (1995), 'Fiscal Flows in the United States and Canada: Lessons for Monetary Union in Europe', European Economic Review 39, 253-274.

Bordignon, M., Manasse, P. and G. Tabellini (2001), 'Optimal Regional Redistribution under Asymmetric Information', American Economic Review 91, 709-723.

Bucovetsky, S., Marchand, M. and P. Pestieu (1998), 'Tax Competition and Revelation of Preferences for Public Expenditures', Journal of Urban Economics 44, 367390. 
Commission of the European Communities (2005), Proposal for a Council Regulation Amending Regulation (EC) No. 1467/97 on Speeding Up and Clarifying the Implementation of the Excessive Deficit Procedure, Brussels (http://europa.eu.int/ comm/economy_finance/publications/sgp_en.htm).

Cornes, R.C. and E.C.D. Silva (2002), 'Local Public Goods, Interregional Transfers and Private Information', European Economic Review 46, 329-356.

Cornes, R.C. and E.C.D. Silva (2003), 'Public Good Mix in a Federation with Incomplete Information', Journal of Public Economic Theory 5, 381-397.

Cremer, H., Marchand, M. and P. Pestieu (1996), 'International Redistribution through Tax Surcharge', International Tax and Public Finance 3, 157-73.

Evans, D.J. and H. Sezer (2004), 'Social Discount Rates for Six Major Countries', Applied Economics Letters 11, 557-560.

Feldstein, M. (2005), 'The Euro and the Stability Pact', NBER Working Paper No. 11249, Cambridge.

Goodspeed, T.J. (2002), 'Bailouts in a Federation', International Tax and Public Finance 9, 409-421.

Huber, B., and M. Runkel (2005), 'Optimal Design of Intergovernmental Grants under Asymmetric Information', International Tax and Public Finance, forthcoming.

Lockwood, B. (1999), 'Inter-regional Insurance', Journal of Public Economics 72, $1-37$.

Mélitz, J., and F. Zumer (2002), 'Regional Redistribution and Stabilization by the Center in Canada, France, the UK and the US: A Reassessment and New Tests', Journal of Public Economics 86, 263-286.

Menegatti, M. (2001), 'On the Conditions for Precautionary Saving', Journal of Economic Theory 98, 189-193.

National Association of State Budget Officers (1992), State Balanced Budget Requirements: Provisions and Practice, Washington, DC: NASBO. 
Peletier, B.D. Dur, R.A.J. and O.H. Schenk (1999), 'Voting on the Budget Deficit', American Economic Review 89, 1377-1381.

Poterba, J.M. (1994), 'State Responses to Fiscal Crises: The Effects of Budgetary Institutions and Politics', Journal of Political Economy 102, 799-821.

Poterba, J.M. (1995), 'Capital Budgets, Borrowing Rules, and State Capital Spending', Journal of Public Economics 56, 165-187.

Poterba, J.M. (1996), 'Budget Institutions and Fiscal Policy in the U.S. States', American Economic Review Papers and Proceedings 86, 395-400.

Poterba, J.M., and K.S. Rueben (2001), 'Fiscal News, State Budget Rules, and TaxExempt Bond Yields', Journal of Urban Economics 50, 537-562.

Raff, H. and J.D. Wilson (1997), 'Income Redistribution with Well-Informed Local Governments', International Tax and Public Finance 4, 407-427.

Schmitt-Grohé, S. and M. Uribe (1997), 'Balanced Budget Rules, Distortionary Taxes, and Aggregate Instability', Journal of Political Economy 105, 976-1000.

Schultz, C. and T. Sjörström (2001), 'Local Public Goods, Debt and Migration', Journal of Public Economics 80, 313-337.

Schultz, C. and T. Sjörström (2004), 'Public Debt, Migration and Shortsighted Politicians', Journal of Public Economic Theory 6, 655-674.

Tabellini, G. and A. Alesina (1990), 'Voting on the Budget Deficit', American Economic Review 80, 37-49.

von Hagen, J. (1991), 'A Note on the Empirical Effectiveness of Formal Fiscal Restraints', Journal of Public Economics 44, 199-210. 


\section{CESifo Working Paper Series}

(for full list see www.cesifo-group.de)

1425 Stephane Dees, Filippo di Mauro, M. Hashem Pesaran and L. Vanessa Smith, Exploring the International Linkages of the Euro Area: a Global VAR Analysis, March 2005

1426 Hans Pitlik, Friedrich Schneider and Harald Strotmann, Legislative Malapportionment and the Politicization of Germany's Intergovernmental Transfer System, March 2005

1427 Konstantinos Angelopoulos and Apostolis Philippopoulos, The Role of Government in Anti-Social Redistributive Activities, March 2005

1428 Ansgar Belke and Daniel Gros, Asymmetries in the Trans-Atlantic Monetary Policy Relationship: Does the ECB follow the Fed?, March 2005

1429 Sören Blomquist and Luca Micheletto, Optimal Redistributive Taxation when Government's and Agents' Preferences Differ, March 2005

1430 Olof Åslund and Peter Fredriksson, Ethnic Enclaves and Welfare Cultures - QuasiExperimental Evidence, March 2005

1431 Paul De Grauwe, Roberto Dieci and Marianna Grimaldi, Fundamental and NonFundamental Equilibria in the Foreign Exchange Market. A Behavioural Finance Framework, March 2005

1432 Peter Egger, Stefan Gruber, Mario Larch and Michael Pfaffermayr, Knowledge-Capital Meets New Economic Geography, March 2005

1433 George Economides and Apostolis Philippopoulos, Should Green Governments Give Priority to Environmental Policies over Growth-Enhancing Policies?, March 2005

1434 George W. Evans and Seppo Honkapohja, An Interview with Thomas J. Sargent, March 2005

1435 Helge Berger and Volker Nitsch, Zooming Out: The Trade Effect of the Euro in Historical Perspective, March 2005

1436 Marc-Andreas Muendler, Rational Information Choice in Financial Market Equilibrium, March 2005

1437 Martin Kolmar and Volker Meier, Intra-Generational Externalities and InterGenerational Transfers, March 2005

1438 M. Hashem Pesaran and Takashi Yamagata, Testing Slope Homogeneity in Large Panels, March 2005

1439 Gjermund Nese and Odd Rune Straume, Industry Concentration and Strategic Trade Policy in Successive Oligopoly, April 2005 
1440 Tomer Blumkin and Efraim Sadka, A Case for Taxing Education, April 2005

1441 John Whalley, Globalization and Values, April 2005

1442 Denise L. Mauzerall, Babar Sultan, Namsoug Kim and David F. Bradford, Charging $\mathrm{NO}_{x}$ Emitters for Health Damages: An Exploratory Analysis, April 2005

1443 Britta Hamburg, Mathias Hoffmann and Joachim Keller, Consumption, Wealth and Business Cycles in Germany, April 2005

1444 Kohei Daido and Hideshi Itoh, The Pygmalion Effect: An Agency Model with Reference Dependent Preferences, April 2005

1445 John Whalley, Rationality, Irrationality and Economic Cognition, April 2005

1446 Henning Bohn, The Sustainability of Fiscal Policy in the United States, April 2005

1447 Torben M. Andersen, Is there a Role for an Active Fiscal Stabilization Policy? April 2005

1448 Hans Gersbach and Hans Haller, Bargaining Power and Equilibrium Consumption, April 2005

1449 Jerome L. Stein, The Transition Economies: A NATREX Evaluation of Research, April 2005

1450 Raymond Riezman, John Whalley and Shunming Zhang, Metrics Capturing the Degree to which Individual Economies are Globalized, April 2005

1451 Romain Ranciere, Aaron Tornell and Frank Westermann, Systemic Crises and Growth, April 2005

1452 Plutarchos Sakellaris and Focco W. Vijselaar, Capital Quality Improvement and the Sources of Growth in the Euro Area, April 2005

1453 Kevin Milligan and Michael Smart, Regional Grants as Pork Barrel Politics, April 2005

1454 Panu Poutvaara and Andreas Wagener, To Draft or not to Draft? Efficiency, Generational Incidence, and Political Economy of Military Conscription, April 2005

1455 Maurice Kugler and Hillel Rapoport, Skilled Emigration, Business Networks and Foreign Direct Investment, April 2005

1456 Yin-Wong Cheung and Eiji Fujii, Cross-Country Relative Price Volatility: Effects of Market Structure, April 2005

1457 Margarita Katsimi and Thomas Moutos, Inequality and Relative Reliance on Tariffs: Theory and Evidence, April 2005 
1458 Monika Bütler, Olivia Huguenin and Federica Teppa, Why Forcing People to Save for Retirement may Backfire, April 2005

1459 Jos Jansen, The Effects of Disclosure Regulation of an Innovative Firm, April 2005

1460 Helge Bennmarker, Kenneth Carling and Bertil Holmlund, Do Benefit Hikes Damage Job Finding? Evidence from Swedish Unemployment Insurance Reforms, May 2005

1461 Steffen Huck, Kai A. Konrad and Wieland Müller, Merger without Cost Advantages, May 2005

1462 Louis Eeckhoudt and Harris Schlesinger, Putting Risk in its Proper Place, May 2005

1463 Hui Huang, John Whalley and Shunming Zhang, Trade Liberalization in a Joint Spatial Inter-Temporal Trade Model, May 2005

1464 Mikael Priks, Optimal Rent Extraction in Pre-Industrial England and France - Default Risk and Monitoring Costs, May 2005

1465 François Ortalo-Magné and Sven Rady, Heterogeneity within Communities: A Stochastic Model with Tenure Choice, May 2005

1466 Jukka Pirttilä and Sanna Tenhunen, Pawns and Queens Revisited: Public Provision of Private Goods when Individuals make Mistakes, May 2005

1467 Ernst Fehr, Susanne Kremhelmer and Klaus M. Schmidt, Fairness and the Optimal Allocation of Ownership Rights, May 2005

1468 Bruno S. Frey, Knight Fever - Towards an Economics of Awards, May 2005

1469 Torberg Falch and Marte Rønning, The Influence of Student Achievement on Teacher Turnover, May 2005

1470 John Komlos and Peter Salamon, The Poverty of Growth with Interdependent Utility Functions, May 2005

1471 Hui Huang, Yi Wang, Yiming Wang, John Whalley and Shunming Zhang, A Trade Model with an Optimal Exchange Rate Motivated by Current Discussion of a Chinese Renminbi Float, May 2005

1472 Helge Holden, Lars Holden and Steinar Holden, Contract Adjustment under Uncertainty, May 2005

1473 Kai A. Konrad, Silent Interests and All-Pay Auctions, May 2005

1474 Ingo Vogelsang, Electricity Transmission Pricing and Performance-Based Regulation, May 2005

1475 Spiros Bougheas and Raymond Riezman, Trade and the Distribution of Human Capital, June 2005 
1476 Vesa Kanniainen, Seppo Kari and Jouko Ylä-Liedenpohja, The Start-Up and Growth Stages in Enterprise Formation: The "New View" of Dividend Taxation Reconsidered, June 2005

1477 M. Hashem Pesaran, L. Vanessa Smith and Ron P. Smith, What if the UK had Joined the Euro in 1999? An Empirical Evaluation Using a Global VAR, June 2005

1478 Chang Woon Nam and Doina Maria Radulescu, Effects of Corporate Tax Reforms on SMEs' Investment Decisions under the Particular Consideration of Inflation, June 2005

1479 Panos Hatzipanayotou, Sajal Lahiri and Michael S. Michael, Globalization, CrossBorder Pollution and Welfare, June 2005

1480 John Whalley, Pitfalls in the Use of Ad valorem Equivalent Representations of the Trade Impacts of Domestic Policies, June 2005

1481 Edward B. Barbier and Michael Rauscher, Trade and Development in a Labor Surplus Economy, June 2005

1482 Harrie A. A. Verbon and Cees A. Withagen, Tradable Emission Permits in a Federal System, June 2005

1483 Hendrik Hakenes and Andreas Irmen, On the Long-Run Evolution of Technological Knowledge, June 2005

1484 Nicolas Schmitt and Antoine Soubeyran, A Simple Model of Brain Circulation, June 2005

1485 Carsten Hefeker, Uncertainty, Wage Setting and Decision Making in a Monetary Union, June 2005

1486 Ondřej Schneider and Jan Zápal, Fiscal Policy in New EU Member States - Go East, Prudent Man!, June 2005

1487 Christian Schultz, Virtual Capacity and Competition, June 2005

1488 Yvan Lengwiler and Elmar Wolfstetter, Bid Rigging - An Analysis of Corruption in Auctions, June 2005

1489 Johannes Becker and Clemens Fuest, Does Germany Collect Revenue from Taxing Capital Income?, June 2005

1490 Axel Dreher and Panu Poutvaara, Student Flows and Migration: An Empirical Analysis, June 2005

1491 Bernd Huber and Marco Runkel, Interregional Redistribution and Budget Institutions under Asymmetric Information, June 2005 